\title{
DoD makes a monkey of anti-missile treaty
}

\section{Washington}

THE Pentagon's Strategic Defence Initiative (star wars) office has produced the first detailed account of how it intends to carry out field tests of new ballistic-missiledefence hardware over the next five years without violating the 1972 Anti-Ballistic Missile (ABM) treaty. The explanation, contained in a report ordered by Congress when it approved the star wars budget last year, is likely only to inflame criticism that the Reagan administration is playing fast and loose with the treaty requirements.

Most of the field tests would be justified on the grounds that they do not involve "ABM components" or "prototypes of ABM components". The treaty does not prohibit the development of weapons to shoot down satellites, cruise missiles or tactical ballistic missiles. So when railguns and rocket-propelled projectiles are tested in Earth orbit in the early 1990s, their targets will be satellites, not missiles. The Department of Defense (DoD) report says that such tests will demonstrate the technology needed to defend space-based ABM battlestations against Soviet anti-satellite weapons. But these technologies are also candidates for ABM systems proper, although DoD says only that the tests will "permit a decision to be made on the applicability of more advanced technology for ABM purposes".

Tests of lasers and space-based tracking systems, on the other hand, would be justified on the grounds that they will have only "limited capability". DoD says because the hardware to be tested is not advanced enough to operate in a fully fledged ABM system, it is not a "prototype". At least some of the limitations may be artificial. Thus a system to track InterContinental Ballistic Missiles (ICBMs) will not qualify as an ABM component prototype because it "may measure the signature of booster plumes, but not in real time".

Congressional critics of Star Wars were quick to point out, after the report was issued last week, that the Pentagon's reliance on the anti-satellite-weapon loophole is further evidence of the Reagan administration's opposition to any progress on a treaty limiting testing of anti-satellite weapons. Representative George Brown (Democrat, California) has called for a renewal of a congressional ban on further anti-satellite testing. He also called plans to test star wars hardware against satellites a "circumvention of the spirit of the ABM treaty".

An analysis by legal scholar Abram Chayes of Harvard University reaches a similar conclusion. He says that attempts to develop star wars technology under the label of anti-satellite or anti-tacticalballistic-missile programmes are "legally disingenuous" as well as technically costly. Chayes points out that the course charted by the Reagan administration will inevitably generate disputes over its legality under the treaty and argues that, instead of being simply a "research" programme that will leave open a decision to renounce the treaty in the mid-1990s and proceed with deployment, star wars as now conceived may make that decision a foregone conclusion.
The DoD report suggests two other ways to get around the provisions of the ABM treaty. The treaty specifically allows field testing of fixed land-based ABM systems or components. This was the administration's justification for the experiment last year in which an interceptor launched from Kwajalein Missile Range in the Pacific hit an ICBM launched from White Sands Missile Range in California. Several further tests of both radars and interceptors is planned under this provision.

The report also hints at a more drastic way to evade the treaty's constraints. Noting alleged Soviet violations of the treaty, the report says "we do reserve the right to respond to those violations in appropriate ways, some of which may eventually bear on the Treaty constraints as they apply to the United States".

Stephen Budiansky

\section{Academics sign on for research}

\section{Washington}

WHATEVER their first reservations, US universities seem to be having no scruples about cashing in on President Reagan's star wars programme of ballistic missile defence, known formally as the Strategic Defense Initiative (SDI). The SDI organization's innovative science and technology of fice, which will spend 5 per cent of the star wars budget, has started to award multimillion dollar contracts to university/industry consortia for basic research with possible applications to missile defences. The office, established only last November, will soon have committed over $\$ 50$ million for basic research. More than 50 US institutions will be working on basic star wars research within the next few months.

The three consortia already named by the innovative science office will be working on non-nuclear power sources suitable for space-based systems ( $\$ 19$ million over four years), optical signal processing (\$9 million over three years) and advanced composite materials ( $\$ 15$ million over three years).

Smaller institutions are not being left out. Besides such well-known research establishments as the California Institute of Technology and Massachusetts Institute of Technology, the consortia include, for example, the University of Texas at Arlington and the University of Alabama at Huntsville.

Applied (as distinct from basic) research, which accounts for the greater part of the SDI budget, is being carried out in-house in government laboratories or in industria companies; several hundred SDI research contracts have already been negotiated. SDI has a total budget of $\$ 26,000$ million over the five years from 1 October 1984.

The director of the innovative science and technology of fice, James Ionson, says he has no illusions about the magnitude of the technical problems confronting SDI, but he is convinced that solutions to many of them will eventually emerge from speculative basic research of the sort supported by his office. According to Dr Ionson, many ideas that at first "seemed crazy" have now demonstrated their potential and will be included in the SDI effort.

All the basic research supported at present through Ionson's office is unclassified, but the classification requirements for SDI research are under scrutiny by the Department of Defense (DoD). Ionson is confident, however, that DoD's policy of relying on classification alone to control oncampus basic research will be maintained.

The recent disruption caused by DoD at a meeting of the Society of Photo-optical Instrumentation Engineers (see Nature 18 April, p.569) raised the possibility that DoD might in future make more use of Export Administration Regulations to restrict the flow of sensitive technology abroad. According to Dr Ionson, use of such regulations is most likely when commercial interests become involved but each case will be considered on its own merits.

Export regulations will undoubtedly be the subject of politically-delicate negotiations if overseas institutions participate in star wars research, because foreign governments will want to ensure that they receive the benefits of technology spin-off. But Defense Secretary Caspar Weinberger has still not given the formal go-ahead for foreign collaboration.

Among the major research threads supported through Dr Ionson's office is optical systolic computing, which could bring within reach the enormous computing power that would be needed for a star wars defence. Ionson is also looking at the possibilities for molecularly engineered dielectrics for capacitors, plasmoid weapons and the protection of satellites in radioactive environments by pumping out the Van Allen radiation belt.

Tim Beardsley 